\title{
Comparison of polymerase chain reaction for antigen receptor gene rearrangement and flow cytometric analysis for the diagnosis of canine lymphoma
}

\author{
Ru-Hui Song, Do-Hyeon Yu', Jun-Hwan Kim, Hyun-Seok Lee, \\ Da-Mi Lee, Chul Park, Il-Jung Yu, Jin-Ho Park ${ }^{*}$ \\ College of Veterinary Medicine, Chonbuk National University, Jeonju 561-756, Korea \\ ${ }^{1}$ College of Veterinary Medicine, University of Missouri, Columbia, MO 65211, USA
}

(Received 29 July 2011; revised 30 August 2011; accepted 2 September 2011)

\section{Abstract}

Lymphoma is the most common hematopoietic malignancy in dogs. Diagnosis of lymphoma is classically performed by morphological assessment and immunohistochemistry. But some cases in the early stage are difficult to distinguish and need more objective and accurate methods. So, Polymerase chain reaction (PCR) for antigen receptor rearrangements (PARR) and flow cytometric immunophenotype of lymphoma have been developed continuously. In this study, we performed these two methods to classify lymphoma type in 3 cases. According to PARR analysis, B cell origin lymphoma was diagnosed in two of three cases by testing PBMC and lymph node. All fine needle aspiration (FNA) samples of lymph nodes had high expression of $\mathrm{CD} 21$ on $>88 \%$ of total cell population and PBMC samples also showed high expression of CD21 on $>30 \%$ of total lymphocytes in those two cases, while the expression of CD3, CD4 and CD8 was absent. These results suggest that concurrent use of PARR and flow cytometric immunophenotype is more effective and valuable tool for the diagnosis and monitoring of canine lymphoma patients.

Key words : Flow cytometry, PARR (PCR for antigen receptor rearrangements), Lymphoma

\section{INTRODUCTION}

Lymphoma is the most common hematopoietic malignancy in dogs and the annual incidence is estimated to be 24 cases in 100,000 dogs (Dorn et al, 1967). Canine lymphoma typically is a diffuse neoplasm resulting in destruction of the lymph node architecture by a monomorphic population of neoplastic lymphocytes (Bartolo and Viswanatha, 2001). This characteristic makes possible to diagnose many canine lymphomas by only cytological test without knowledge of node architecture (Gibson et al, 2004).

So, diagnosis of lymphoma is easily performed by morphological assessment and immunohistochemistry. But

\footnotetext{
*Corresponding author: Jin-Ho Park, Tel. +82-63-270-2557,

Fax. +82-63-270-3780, E-mail. jpark@jbnu.ac.kr
}

other methods like Polymerase chain reaction (PCR) for antigen receptor gene rearrangements (PARR) and flow cytometric immunophenotype are needed. For example, in the case of any suspect B-cell proliferations when morphology and immunophenotyping are not conclusive; all suspect T-cell proliferations; lymphoproliferations in immunodeficient patients, including post-transplant patients; evaluation of the clonal relationship between two lymphoid malignancies in one patient or discrimination between a relapse and a second malignancy; further classification of a malignancy via $\mathrm{Ig} / \mathrm{TCR}$ gene rearrangement patterns or particular chromosome aberrations; staging of lymphomas; the early stage of disease; difficult to distinguish, flow cytometric immunophenotype and PARR should be performed (Culmsee et al, 2001; Culmsee and Nolte, 2002; van Dongen et al, 2003). 
In veterinary medicine, more researches about these two methods for canine lymphoma are needed. So we performed these two methods to classify lymphoma type in 3 cases.

\section{MATERIALS AND METHODS}

\section{Animals}

We examined one castrated male dog and two female dogs. Two of them were admitted to Animal Medical Center of Chonbuk National University and one was referred to Haemaru Animal hospital. Samples of three dogs were requested for PCR amplification test and FACS analysis at our laboratory.

All the dogs presented generalized enlarged lymph nodes, anorexia, depression and abdominal distention. They were diagnosed as multicentric lymphoma based on cytological examination. Case 1 was a seven-year-old neutered male Shih-Tzu was presented for anorexia, lethargy and generalized enlarged lymph nodes. It was stage $4 \mathrm{~b}$ of WHO criteria on cytological examination. Case 2, a fiveyear-old female schnauzer, was admitted with the history of generalized enlarged lymph nodes, depression, inappetence, tachypnea and abdominal distention. Clinicopathologic revealed mild leukopenia, anemia and slightly increased alkaline phosphatase (ALP $508 \mathrm{U} / \mathrm{L}$ ).

In diagnostic imaging, splenomegaly and enlarged sublumbar lymph node were shown. And high-grade lymphoma was diagnosed. The size of more than $80 \%$ of total lymphocytes was medium to large. Case 3, an unknown aged female Shih-Tzu, was presented for ascites, icterus, generalized enlarged lymph nodes, edema and melena. This case was stage $5 \mathrm{~b}$.

\section{Sample collection}

FNA samples of the neoplastic lymph nodes were obtained and used for cytological test, flow cytometric analysis and PARR. For flow cytometric immunophenotype, the samples were diluted in PBS and remaining cells were immediately stored at $-20^{\circ} \mathrm{C}$ until used.

For isolation of Canine PBMC, blood was collected in- to $6 \mathrm{ml}$ potassium EDTA treated tubes. Peripheral blood mononuclear cells (PBMC) were immediately isolated by centrifugation at $700 \times \mathrm{g}$ for $30 \mathrm{~min}$ through Histopaque ${ }^{(\mathbb{R}}$ 1,119 and 1,077 (Sigma-Aldrich, St. Louis, Mo, U.S.A.) The PBMC layer was harvested. $5 \mathrm{ml}$ of lysis buffer (83\% ammonium chloride solution, $\mathrm{pH}$ 7.2) was added to remove the residual $\mathrm{RBC}$ and incubated for $5 \mathrm{~min}$ and then, centrifuged at $200 \times \mathrm{g}$ for $10 \mathrm{~min}$. PBMC that removed residual $\mathrm{RBC}$ were washed twice with PBS by centrifugation at $200 \times \mathrm{g}$ for $10 \mathrm{~min}$. Cell counts were assessed by VET ABC impedance cell counter. Cell purity was determined by a conventional diff-quick method.

\section{Detection of the rearrangements of antigen receptor genes by using PCR}

Genomic DNA was extracted from FNA samples and PBMCs of patients using the QIAamp Blood mini kit (Qiagen). $100 \mathrm{ng}$ of genomic DNA was amplified using 4 sets of primer for $\mathrm{V}$ and $\mathrm{J}$ regions. Amplification of immunoglobulin and T-cell receptor gamma sequences was performed using previously described primers (Burnett et al, 2003).

Primers used for the amplification of Ig major and minor CDR3 and TCR $\gamma$ CDR3 sequences are, CB1/CB2 (5'-CAG CCT GAG AGC CGA GGA CAC-3'/5'-TGA GGA GAC GGT GAC CAG GGT-3'), CB1/CB3 (5'-CAG CCT GAG AGC CGA GGA CAC-3'/5'-TGA GGA CAC AAA GAG TGA GG-3') and TCR $\gamma 1 /$ TCR $\gamma 2 /$ TCR $\gamma 3$ (5'-ACC CTG AGA ATT GTG CCA GG-3'/5'-GTT ACT ATA AAC CTG GTA AC-3'/ 5'-TCT GGG A/GTG TAC/T TAC TGT GCT GTC TGG-3'), respectively.

To ensure the DNA could be amplified, positive control primers were used to amplify the constant region gene of $\operatorname{IgM}(\mathrm{C} \mu)$. The primers of $\mathrm{C} \mu$ are Sigmf1/Sr $\mu 3$ (5'-TTC CCC CTC ATC ACC TGT GA-3'/5'-GGT TGT TGA TTG CAC TGA GG-3'). After PCR amplification, the PCR products were analyzed by $12.5 \%$ native polyacrylamide gel electrophoresis.

\section{Flow cytometry}

Flow cytometry was performed with the BD flow 
cytometer. The samples were vortex briefly before analysis and 10,000 events of lymphocytes per tube were acquired. Measured data was evaluated with Cell Quest software. A lymphocyte gate was established using forward scatter and side scatter that respectively relate to cell dimension and cytoplasm complexity.

Within the gate, percentages of subpopulations were calculated by establishing parameters for fluorescence (FITC, PE, of Alexa). Antibodies of CD3, 4, 8 and 21 were used (Table 1). Positive results for CD3, 4, 8 were judged by $\mathrm{T}$-cell line and cases reacting against CD21 were classified as B-cell lymphomas.

\section{RESULTS}

\section{Detection of antigen receptor gene rear- rangements}

Every lymph node FNA samples of three cases showed that Ig $\mathrm{H}$ major genes which were specific for the majority of immunoglobulin gene rearrangements were amplified (Fig. 1). According to PARR analysis, all three dogs were diagnosed as B-cell lymphoma. But, in only two of three cases, B cell origin lymphocytes were detected in both PBMCs and lymph node samples. One case was not amplified in PBMC samples.

Table 1. Antibodies used to classify lymphocytes in samples from canine lymphoma patients

\begin{tabular}{llc}
\hline \multicolumn{1}{c}{ Antigen } & Conjugation & Leukocyte subpopulation \\
\hline Canine CD3 & FITC* $^{*}$ & T lymphocytes \\
Canine CD4 & PE $^{\dagger}$ & T-helper cells \\
Canine CD8 & Alexa & Cytotoxic T cells \\
Canine CD21 & PE & B lymphocates \\
\hline
\end{tabular}

*Fluorescein isothiocyanate, ${ }^{\dagger}$ Phycoerythrin.

\section{Immunophenotyping}

All FNA samples of lymph node had high expression of $\mathrm{CD} 21$ on $>88 \%$ of all cells and lacked expression of CD3, CD4 and CD8 (Table 2). In two cases, PBMC samples also showed high expression of CD21 on $>30 \%$ of all lymphocytes. And in one case, PBMC sample had normal expression of CD21, CD3, CD4, and CD8.

\section{DISCUSSION}

Immunophenotyping of FNA samples from enlarged lymph nodes or other sites is a crucial component of the refined diagnosis of lymphoproliferative disease in humans (Sandhaus, 2000). And the information that distributions of specific antigens expressed by neoplastic lymphocytes is associated with therapeutic and prognostic determinants, so it is very important and necessary for diagnosis of lymphoma (Greenlee et al, 1990; Ruslander et al, 1997; Vernau and Moore, 1999).

In veterinary medicine, however, diagnosis and response to therapy of lymphoma is primarily evaluated

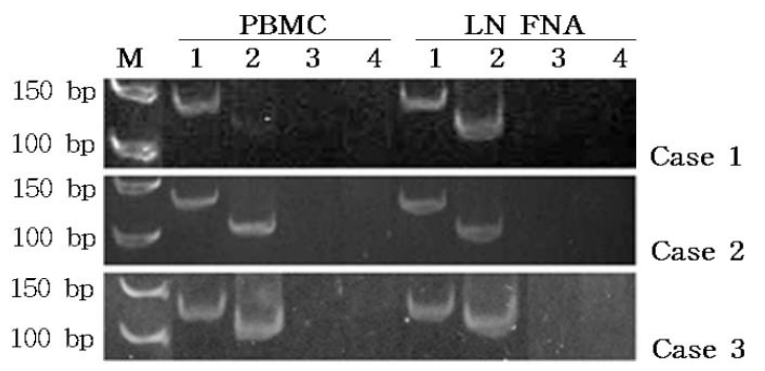

Fig. 1. The results of PARR. Lane M: molecular size marker, lane 1: Control (130 bp), lane 2: B cell origin-IgH major (120 130 bp), lane 3: B cell origin-IgH minor (120 130 bp), lane 4: T cell origin $(90 \sim 100 \mathrm{bp})$.

Table 2. Flow cytometric results of PBMCs and lymph node FNA samples in 3 cases

\begin{tabular}{|c|c|c|c|c|c|c|c|c|}
\hline \multirow{2}{*}{ Antigen } & \multicolumn{4}{|c|}{ PBMC } & \multicolumn{4}{|c|}{ LN FNA } \\
\hline & CD3 & CD4 & $\mathrm{CD} 8$ & $\mathrm{CD} 21$ & CD3 & $\mathrm{CD} 4$ & $\mathrm{CD} 8$ & CD21 \\
\hline Normal range (\%) & $78.5 \sim 80.5$ & $25.2 \sim 36.6$ & $13.7 \sim 24.0$ & $12.2 \sim 15.5$ & $45.7 \sim 63.4$ & $18.7 \sim 25.5$ & $7.3 \sim 10.7$ & $24.7 \sim 38.0$ \\
\hline Case 1 & 80.4 & 35.8 & 20.1 & 10.8 & 2.4 & 1.3 & 0.4 & 96.7 \\
\hline Case 2 & 38.0 & 17.6 & 19.1 & 33.1 & 10.9 & 4.3 & 5.1 & 88.1 \\
\hline Case 3 & 1.3 & 0.7 & 0.7 & 91.2 & 3.0 & 6.8 & 1.6 & 96.1 \\
\hline
\end{tabular}


on the basis of lymph node size and cytomorphological examination of FNA only. But cytomorphology has a very low sensitivity and specificity (detects five neoplastic cells per 100 normal cells) (Bartolo and Viswanatha, 2001).

In 1994 the First International Canine Leucocyte Antigen Workshop identified a variety of canine specific antibodies that reacted with leucocytes, particularly lymphocytes (Greenlee et al, 1990; Cobbold and Metcalfe, 1994). In practice, now, assessment of immunophenotype is relatively widespread in canine lymphomas compared to leukemia, because of its prognostic significance (Greenlee et al, 1990). The most common technique for immunophenotypic characterization of canine lymphoma is immunohistochemistry (Kiupel et al, 1999; Culmsee et al, 2001; Culmsee and Nolte, 2002). And the merits of this method is that these antibodies are reactive with formalin fixed tissues and that the architecture of the node and the morphology of the cells can be evaluated concurrently (Moore and Vernau, 2000).

Flow cytometry enables to analyze multiple characteristics of the large number of single cells rapidly (Dunphy and Ramos, 1997; Culmsee and Nolte, 2002), and to assess lymphocytes by defined and objective criteria (Sandhaus, 2000). Also, flow cytometry can improve the sensitivity of detection (61 neoplastic cells per 100 normal cells) and is inexpensive to perform (Comazzi and Gelain, 2011). Therefore, flow cytometric method provides statistically robust indices that have made this diagnostic approach valuable in human oncology (Dunphy and Ramos, 1997; Sandhaus, 2000).

In human medicine, flow cytometry has developed to a crucial and usual tool in the diagnosis of hematopoietic malignancies, especially lymphomas, in recent years (Dunphy and Ramos, 1997; Das, 2006). And it is a rapid, simple and inexpensive method, so that the detection of clonality in B cell lymphomas using flow cytometry is often used as a main method (Das, 2006). Also, it is commonly used for lineage assignment, analysis of cellular maturation and heterogeneity within the malignant cell population as well as detection of minimal residual disease and monitoring of disease in human lymphoma (Rothe and Schmitz, 1996).
Similarly, in veterinary clinical laboratory, flow cytometry has shown to be an appropriate method for immunophenotyping of canine lymphomas and the use of flow cytometry has been evolved considerably during the past decade (Culmsee and Nolte, 2002; Weiss, 2002). But, the approach has not been performed essentially in veterinary medicine yet (Grindem, 1996; Culmsee et al, 2001; Culmsee and Nolte, 2002; Weiss, 2002), and the level of complexity, sophistication and importance which immunophenotyping has achieved is far lower in comparison to humane medicine (Culmsee and Nolte, 2002). Besides a report associated with immunophenotyping of lymphoma using flow cytometry is not in Korea. However its value for lymphoma in animals has been stressed (Grindem, 1996).

Unfortunately, flow cytometers are not simple instruments and the device costs are relatively expensive. Also, trained personnel are required and the paucity of specific antibodies is a problem to use it in dog routinely (Culmsee and Nolte, 2002; Comazzi and Gelain, 2011). As other limitations, veterinary laboratories that performed flow cytometric method of lymphoma are very few. So, samples can be dispatched to referral laboratories suspended in RPMI medium and chilled. Time restriction may be involved because the cells should then be processed within $24 \mathrm{~h}$ (Culmsee and Nolte, 2002; Gibson et al, 2004; Comazzi and Gelain, 2011).

Nevertheless, flow cytometric analysis of canine lymphoma cells is a reliable technique which can be recommended for the determination of the immunophenotype of tumor cells (Culmsee et al, 2001) and it is advancing our knowledge of canine lymphomas (Culmsee and Nolte, 2002). Moreover, the method will certainly play an increasingly important role in diagnosis and therapy of canine lymphoma, as has been the case in recent years in human medicine (Culmsee et al, 2001).

In $\mathrm{B}$ cells, recombination of the $\mathrm{V}, \mathrm{D}$, and $\mathrm{J}$ gene segments produces the CDR3 (complementarity determining region 3) that encodes the antigen-binding portion of the immunoglobulin(Ig) heavy chain. In $\mathrm{T}$ cells, the unique CDR3 region encoding T-cell receptor gamma (TCR $\gamma)$ is produced by recombination of the $\mathrm{V}$ and J regions (Raulet, 1989; Schatz et al, 1992). PARR depends on the amplification of tumor markers such as 
specific chromosome aberrations or Ig chain and T-cell receptor (TCR) rearrangements based on the presumption that all cells of a malignancy have a common clonal origin (Raulet, 1989). So, after PCR analysis with primers for conserved regions of the $\mathrm{V}$ and $\mathrm{J}$ genes, a dominant band is shown, it means that the samples have a population of cells bearing a single-sized receptor (i.e., a clonal expansion) (Burnett et al, 2003).

The amplification using PCR of novel genetic material created by translocation allows for detection of as few as 1 neoplastic cell in $10^{6}$ cells (Morley, 1998). And it can detect neoplastic lymphocytes in peripheral blood 2.5 times more frequently than did microscopy (Yu et al, 2009). So PARR is an objective and highly sensitive method to detect clonal populations of $\mathrm{B}$ or $\mathrm{T}$ lymphocytes (Burnett et al, 2003). The sensitivity of PARR for detecting lymphoma cells may provide a noninvasive method for detecting lymphoma in its early stages, determining phenotype, monitoring therapy, screening breeds at risk for lymphoma, and possibly for assessing prognosis (Keller et al, 2004). Also, this method can be applied for the diagnosis of lymphoma from limited biopsy samples, formalin-fixed/paraffin-embedded tissues (Wan et al, 1990; Tai and Peh, 2003), or even sections already mounted on slides and stained (Fend et al, 1999; Yu et al, 2009). And unlike other molecular techniques, PARR does not require high molecular weight DNA for successful analysis of biological specimens. Thus, it could be ideally suitable to use a template extracted from archival clinical specimens for PARR. As such, it allows large-scale retrospective studies (Poljak et al, 1995; Vince et al, 1998).

Actually, in human medicine, molecular techniques using polymerase chain reaction promote the diagnostic analysis of clinical cases of lymphoma by detection of the clonal gene rearrangement (Mitterbauer-Hohendanner et al, 2004; Xu et al, 2004; Bahloul et al, 2005). As well as, detection of clonality generally has been used to distinguish neoplasia from hyperplasia, for detecting minimal residual disease after chemotherapy in leukemia, and as a sensitive test for detecting circulating tumor cells in peripheral blood (Lana et al, 2006). So, nowadays, it is evaluated that as many as $10 \%$ of clinical laboratory tests are based on PCR (Qualman et al,
2004).

In some veterinary studies, clinical stage of canine malignant lymphoma is considered a prognostic factor, because infiltration into the bone marrow or disease in the peripheral blood was represented a worse prognosis (Vail and Young, 2007). The stage of canine lymphoma is currently diagnosed primarily by morphological assessment of lymphoid tissue based on subjective lightmicroscopic assessments (Keller et al, 2004; Tamura et al, 2006). Although this definition of stage V lymphoma appears easy, microscopic criteria are subjective and varied to detect neoplastic cells in lymph node and peripheral blood. According to a study, the rate of leukemic involvement of peripheral blood ranges from $28 \%$ to $65 \%$ in dogs with multicentric lymphoma, and depends on the stringency of criteria used (Keller et al, 2004). Thus, the assessment of clonal rearrangements of antigen receptor genes using PCR has been introduced into veterinary medicine, recently (Vernau and Moore, 1999; Burnett et al, 2003; Keller et al, 2004; Tamura et al, 2006; Yagihara et al, 2007). Also, in Korean veterinary clinics, diagnosis of canine $\mathrm{B}$ cell or $\mathrm{T}$ cell lymphoma using PCR was often carried out in case of uncertain if it is polyclonal or monoclonal lymphocytes.

On the other hand, several limitations and pitfalls might hamper the interpretation of the molecular diagnosis in the cases of false-positive results and ambiguity due to pseudoclonality and oligoclonality. However, visual detection of neoplastic cells or flow cytometric analysis in canine lymphoma is relatively insensitive when compared with detection by PARR (Keller et al, 2004).

In this study, we compared our canine lymphoma patients with that previously reported in the literature with regard to flow cytometric immunophenotype both in PBMC and in lymph node aspirates of normal dogs. In the data of $\mathrm{LN}$ aspirates, all cases showed CD21 positive expression, respectively $96.73 \%, 88.1 \%$ and $96.06 \%$. It is much high level compared with normal reference ranges (Gibson et al, 2004) and this indicates that the patients are $\mathrm{B}$ cell origin lymphoma. Also, we were made a comparison the data of $\mathrm{PBMC}$ and normal ranges of other reports (Byrne et al, 2000). One case was shown normal level in $\mathrm{CD} 3,4,8$ and 21 expression percentage of PBMC and the remaining two were revealed 
high expression of CD 21 in PBMC. This represent that the two cases had tumor cells in peripheral blood and it correspond to stage $\mathrm{V}$ of $\mathrm{WHO}$ criteria.

Additionally, we performed PARR with all LN aspirates and PBMC samples and the results were same to flow cytometric analysis. In all samples, except PBMC of case 1 , Ig $\mathrm{H}$ major gene was amplified, so we diagnosed them as B cell origin lymphoma.

In veterinary medicine, a few studies using these two methods at once were reported, according to a research of Vernau and Moore (1999) immunophenotype is useful to distinguish characteristic of lymphoid cells, but it can be difficult to differentiate a reactive lymphoid proliferation from a neoplastic one in some circumstances. Therefore, it is indicated that demonstration of clonality should be performed as an adjunct to phenotypic studies (Vernau and Moore, 1999). Consequently, PCR analysis was also performed, and we compared our PCR data and flow cytometric data in 3 cases. The PCR data coincided with flow cytometric immunophenotype as B cell origin lymphoma excepting a PBMC sample of case 1.

In canine lymphoma, advantages of the flow cytometric analysis are rapidity and more detailed to differentiate diverse cell surface antigen compared with PCR method. However, PCR based clonality assay is more sensitive and validated (Vernau and Moore, 1999). Thus, concurrently using of flow cytometric immunophenotype and PARR for canine lymphoma may be complementary to check up the lymphoma status and more effective and valuable tool to diagnosed and monitored canine lymphoma patients.

In concluded, the integration of immunophenotypic and clonality assessment should be performed to diagnosed canine lymphoma with historical, clinical, cytological and histological information.

\section{REFERENCES}

Bahloul M, Asnafi V, Macintyre E. 2005. Clinical impact of molecular diagnostics in low-grade lymphoma. Best Pract Res Clin Haematol 18: 97-111.

Bartolo C, Viswanatha DS. 2001. Molecular methods for minimal residual disease detection in hematolymphoid diseases: principles and applications. J Clini Ligand Assay 24:
76-93.

Burnett RC, Vernau W, Modiano JF, Olver CS, Moore PF, Avery AC. 2003. Diagnosis of canine lymphoid neoplasia using clonal rearrangements of antigen receptor genes. Vet Pathol 40: 32-41.

Byrne KM, Kim HW, Chew BP, Reinhart GA, Hayek MG. 2000. A standardized gating technique for the generation of flow cytometry data for normal canine and normal feline blood lymphocytes. Vet Immunol Immunopathol 73: 167-182.

Cobbold S, Metcalfe S. 1994. Monoclonal antibodies that define canine homologues of human CD antigens: summary of the First International Canine Leukocyte Antigen Workshop (CLAW). Tissue Antigens 43: 137-154.

Comazzi S, Gelain ME. 2011. Use of flow cytometric immunophenotyping to refine the cytological diagnosis of canine lymphoma. Vet J 188: 149-155.

Culmsee K, Nolte I. 2002. Flow cytometry and its application in small animal oncology. Methods Cell Sci 24: 49-54.

Culmsee K, Simon D, Mischke R, Nolte I. 2001. Possibilities of flow cytometric analysis for immunophenotypic characterization of canine lymphoma. J Vet Med A Physiol Pathol Clin Med 48: 199-206.

Das DK. 2006. Serous effusions in malignant lymphomas: a review. Diagn Cytopathol 34: 335-347.

Dorn CR, Taylor DO, Hibbard HH. 1967. Epizootiologic characteristics of canine and feline leukemia and lymphoma. Am J Vet Res 28: 993-1001.

Dunphy CH, Ramos R. 1997. Combining fine-needle aspiration and flow cytometric immunophenotyping in evaluation of nodal and extranodal sites for possible lymphoma: a retrospective review. Diagn Cytopathol 16: 200-206.

Fend F, Quintanilla-Martinez L, Kumar S, Beaty MW, Blum L, Sorbara L, Jaffe ES, Raffeld M. 1999. Composite low grade B-cell lymphomas with two immunophenotypically distinct cell populations are true biclonal lymphomas. A molecular analysis using laser capture microdissection. Am J Pathol 154: 1857-1866.

Gibson D, Aubert I, Woods JP, Abrams-Ogg A, Kruth S, Wood RD, Bienzle D. 2004. Flow cytometric immunophenotype of canine lymph node aspirates. J Vet Intern Med 18: 710-717.

Greenlee PG, Filippa DA, Quimby FW, Patnaik AK, Calvano SE, Matus RE, Kimmel M, Hurvitz AI, Lieberman PH. 1990. Lymphomas in dogs. A morphologic, immunologic, and clinical study. Cancer 66: 480-490.

Grindem CB. 1996. Blood cell markers. Vet Clin North Am Small Anim Pract 26: 1043-1064.

Keller RL, Avery AC, Burnett RC, Walton JA, Olver CS. 2004. Detection of neoplastic lymphocytes in peripheral blood of dogs with lymphoma by polymerase chain reaction for antigen receptor gene rearrangement. Vet Clin Pathol 33: 145-149.

Kiupel M, Teske E, Bostock D. 1999. Prognostic factors for treated canine malignant lymphoma. Vet Pathol 36: 292-300. 
Lana SE, Jackson TL, Burnett RC, Morley PS, Avery AC. 2006. Utility of polymerase chain reaction for analysis of antigen receptor rearrangement in staging and predicting prognosis in dogs with lymphoma. J Vet Intern Med 20: 329-334.

Mitterbauer-Hohendanner G, Mannhalter C, Winkler K, Mitterbauer M, Skrabs C, Chott A, Simonitsch-Klupp I, Gleiss A, Lechner K, Jaeger U. 2004. Prognostic significance of molecular staging by PCR-amplification of immunoglobulin gene rearrangements in diffuse large B-cell lymphoma (DLBCL). Leukemia 18: 1102-1107.

Moore PF, Vernau W. 2000. Lymphocytes: differentiation molecules in diagnosis and prognosis. pp. 247-255. In: Feldman BF, Zinkl JG, Schalm OW(ed.). Schalm's veterinary hematology. Lippincott Williams \& Wilkins, Philadelphia.

Morley A. 1998. Quantifying leukemia. N Engl J Med 339: 627-629.

Poljak M, Barlic J, Seme K, Avsic-Zupanc T, Zore A. 1995. Isolation of DNA from archival Papanicolaou stained cytological smears using a simple salting-out procedure. Clin Mol Pathol 48: M55-56.

Qualman SJ, France M, Grizzle WE, LiVolsi VA, Moskaluk CA, Ramirez NC, Washington MK. 2004. Establishing a tumour bank: banking, informatics and ethics. Br J Cancer 90: 1115-1119.

Raulet DH. 1989. The structure, function, and molecular genetics of the gamma/delta $\mathrm{T}$ cell receptor. Annu Rev Immunol 7: 175-207.

Rothe G, Schmitz G. 1996. Consensus protocol for the flow cytometric immunophenotyping of hematopoietic malignancies. Working Group on Flow Cytometry and Image Analysis. Leukemia 10: 877-895.

Ruslander DA, Gebhard DH, Tompkins MB, Grindem CB, Page RL. 1997. Immunophenotypic characterization of canine lymphoproliferative disorders. In Vivo 11: 169-172.

Sandhaus LM. 2000. Fine-needle aspiration cytology in the diagnosis of lymphoma. The next step. Am J Clin Pathol 113: 623-627.

Schatz DG, Oettinger MA, Schlissel MS. 1992. V (D) J recombination: molecular biology and regulation. Annu Rev Immunol 10: 359-383.

Tai YC, Peh SC. 2003. Immunoglobulin gene rearrangement of lymphoid malignancies : Application of the PCR technique to formalin-fixed, paraffin-embedded tissues. J Clin Exp Hematopathol 43: 1-10.

Tamura K, Yagihara H, Isotani $\mathrm{M}$, Ono $\mathrm{K}$, Washizu $\mathrm{T}$,
Bonkobara M. 2006. Development of the polymerase chain reaction assay based on the canine genome database for detection of monoclonality in B cell lymphoma. Vet Immunol Immunopathol 110: 163-167.

Vail DM, Young KM. 2007. Canine lymphoma and lymphoid leukemia. pp. 699-733. In: Withrow SJ, Vail DM(ed.). Withrow and MacEwen's Small Animal Clinical Oncology. 4th ed. Saunders Elsevier, Missouri.

van Dongen JJ, Langerak AW, Brüggemann M, Evans PA, Hummel M, Lavender FL, Delabesse E, Davi F, Schuuring E, García-Sanz R, van Krieken JH, Droese J, González D, Bastard C, White HE, Spaargaren M, González M, Parreira A, Smith JL, Morgan GJ, Kneba M, Macintyre EA. 2003. Design and standardization of PCR primers and protocols for detection of clonal immunoglobulin and T-cell receptor gene recombinations in suspect lymphoproliferations: report of the BIOMED-2 Concerted Action BMH4-CT98-3936. Leukemia 17: 2257-2317.

Vernau W, Moore PF. 1999. An immunophenotypic study of canine leukemias and preliminary assessment of clonality by polymerase chain reaction. Vet Immunol Immunopathol 69: 145-164.

Vince A, Poljak M, Seme K. 1998. DNA extraction from archival Giemsa-stained bone-marrow slides: comparison of six rapid methods. Br J Haematol 101: 349-351.

Wan JH, Trainor KJ, Brisco MJ, Morley AA. 1990. Monoclonality in B cell lymphoma detected in paraffin wax embedded sections using the polymerase chain reaction. $\mathrm{J}$ Clin Pathol 43: 888-890.

Weiss DJ. 2002. Application of flow cytometric techniques to veterinary clinical hematology. Vet Clin Pathol 31: 72-82.

Xu D, Du J, Kamino H, Ratech H. 2004. Rapid diagnosis of clonal immunoglobulin heavy chain gene rearrangements in cutaneous B-cell lymphomas using the LightCyclerPolymerase Chain Reaction with DNA melting curve analysis. Am J Dermatopathol 26: 385-389.

Yagihara $\mathrm{H}$, Tamura $\mathrm{K}$, Isotani $\mathrm{M}$, Ono $\mathrm{K}$, Washizu $\mathrm{T}$, Bonkobara M. 2007. Genomic organization of the T-cell receptor gamma gene and PCR detection of its clonal rearrangement in canine T-cell lymphoma/leukemia. Vet Immunol Immunopathol 115: 375-382.

Yu DH, Li YH, Lee JH, Noh DH, Song RH, Lee MJ, Choi US, Park JH. 2009. Detection of canine lymphoma by the amplification of antigen receptor gene rearrangements. J Vet Clin 26: 419-422. 